\title{
Intellectualism as a Catalyst for Sustainable Development in Nigeria
}

\author{
Aaron Onyemaechi Nwokolo \\ http://dx.doi./org/10.4314/ujah.v21i4.15
}

\begin{abstract}
Knowledge, research and intellectual input are veritable instruments for the advancement of any state. Intellectuals help to shape and formulate policies that can stimulate development. This paper examined the various intellectual contributions by scholars and researchers towards unlocking and enhancing development in Nigeria. It further discussed how intellectual discourse can help to unravel opportunities for socio-political and economic development of Nigeria.
\end{abstract}

Keywords: Intellectualism, Stimulation, Sustainable, Development

\section{Introduction}

It is incontrovertible that political stability creates the enabling environment for development in any society. Since Nigeria gained political in dependence in 1960, she had a checkered political history. The first being the 1966 military coup followed by the counter coup which led to the unfortunate Nigeria civil war and unlimited chain of military coups both the successful and the unsuccessful. Military intervention in politics is unhealthy to democratic consolidation which creates the required institutional base for development Adebeyo (1981:174) argues.

When a weak personality of limited intelligence suddenly appears by accident of history at the summit of human affairs, the consequences are often disastrous. It becomes tragic when such an individual is clothed with autocratic powers to assume responsibility 
for the government in his own person aloe. Very often, these ill equipped military personnel added the last straw by becoming morally notorious in their states for over-familiarity with the bottle and with women of easy virtue.

For a sustainable development to be achieved in Nigeria, there must be an end to all the remaining vestiges of military rule in the country in order to avoid discontinuities in policy planning and loss of high level manpower in the country.

As an integral part of the modern world, Nigerians are highly and rightly concerned about its development. The development of a nation does not come by accident rather it is a product of a conscious effort by men and women with vision and resolve. Development is therefore a product of conscious statecraft, not happenstance. Developing a nation is always a work-in-progress, a dynamic process in constant need of nurturing and re-invention. Development of a nation never stops arid true national builders never rest because all nations are constantly facing up to new challenges. Development of a nation has many important aspects. Firstly, it is about building a political entity which corresponds to a given form, based on some generally accepted rules norms, principles and a common citizenship.

Secondly, it is also about building institutions which symbolize the political entity-institutions such as a bureaucracy, an economy, the judiciary, universities, a civil service, and civil society organizations. Above all else, however, development is about building a common sense of purpose, a sense of shared destiny, a collective imagination of belonging. Development is about building the tangible and intangible threads that hold a political entity together and gives it a sense of purpose even these days of globalization and rapid informational flows of people and ideas, having a viable nation remains synonymous with achieving modernity. It is about building the institutions and values which sustains the collective community in these modern times. 
In Nigeria, however there are some people who represent our national importance by calling us the "Giant of Africa". This is an ascriptive perspective, we are seen as giants riot necessarily because of the quality of our national institutions and values; but simply by virtue of our large population and oil wealth, but in reality, the greatness of nation has to be earned and is not determined just by the size of its population or the* abundance of its natural 'resources. China and India have the largest populations in the world, but they are only now rising as important global players. On the other hand, Japan has few natural resources, but has long managed to shows itself as a global economic pointer house.

In today's world, skills, industriousness, productivity, and competitiveness are the determinant factors of national greatness. Not even the possession of the nuclear bomb is enough to make a nation great without reference to the industriousness and creativity of its citizens, since the time of Adam smith, every serious nationalist and politician has come to know that the wealth of a nation is riot based on the wealth and opulence of its rulers, but on the productivity and industriousness of its citizenry.

The real question is why has the task of national development been so difficult in Nigeria, and the fruits so patchy, despite our enormous human and natural resource? I suggest that we should look for the answer in three critical areas:

i. Threats and challenges posed by the environment for development.

ii. The quality of leadership that has confronted these challenges.

iii. The fragility of political and development institutions.

We need to understand the environment for development in Nigeria, so we can clearly identify our strengths, weaknesses, and core challenges, we also need to evolve a system of leadership selection and acceptability which produces the; sort of leaders that 
will confront the challenges of the environment in a Way that is beneficial for development. Nations are a product of the human will and imagination and the institutions that sustain their collective efforts.

\section{Challenges Facing Nigerians Development}

Nigeria faces five main development challenges:

1. The challenges from our history

2. The challenge of socio-economic inequalities

3 . The challenges of an appropriate constitutional settlement.

4. The challenges of building institutions for democracy and development.

5. The challenges of leadership.

In our quest for development, we have recorded some successes, such as keeping the country together in the face of many challenges. But these challenges continue to keep us away from achieving our full potentials.

\section{The Challenge of History}

The historical legacies of colonial rule create some challenges for development in Nigeria Colonial rule divided Nigeria into north and south with different land tenure .systems,; local government administration, educational systems and judicial systems, while large British colonies like India and the Sudan had a single administrative system, Nigeria had two; one for the north and one for the south it was almost as if these were two separates countries, held together only by a shared currency and transportation system. Many members of the Nigerian elite class in the 1950's and 1960's had their education and world outlook molded by the regional institutions. Some had little or no understanding of their neighbouring regions. Under these conditions it, was easy for prejudice and fear to thrive. During the 
period of the colonization struggle Nigerian nationalist from different regions fought each other as much as they fought the British colonialists. Nigeria never had a central rallying figure like Kwama Nkrumah in Ghana or Nelson Mandela in South Africa. Instead, each region thrown up its own champions.

From this historical legacy therefore, regionalism has been a major challenge to development in Nigeria. To their credit however, the founding fathers of our nation tried to deal with this challenge by adopting federalism and advocating a policy of unity in diversity unfortunately, the lack of consolidation of Nigerian federalism around commonly shared values and positions means that this challenge of divisive historical legacy continues to undermine our efforts at development. One current manifestation of this historical legacy is the division between "Indigeres" and "settlers". The division has been a source of domestic tension and undermined our efforts at creating a common nation hook. We should learn from history so as not to repeat its mistakes, we must never see ourselves simply as victims of our industry, it is our responsibility to overcome the challenges posed by our history.

\section{The Challenges of Socio-Economic Inequality}

A very important aspect of development is the building of a common citizenship, but how can we have a common citizenship when the person in Abia has a radically different quality of life from the person in Ibadan? Through the development of the economy and equal opportunities for all, or through the development of social welfare safety nets, mature nations try to establish a base line of social and economic rights which all members of the national community must enjoy. Not to enjoy these socio-economic rights means that the people involved are marginalized from national life. That is why in many western European countries, contemporary development is about preventing "social exhaustion" or the exclusion of significant 
segments of the population from enjoying basic social and comic rights.

In Nigeria, however, not only are many of our citizens denied basic rights such as the right to education and health, there is also serious variation in the enjoyment of these rights across the country. As a consequence, the citizen is not motivated to support the state and society, because he or she does not feel that the society is adequately concerned about their welfare. Secondly socio-economic inequalities across the country fuels fears and suspicion which keep our people divided and ill-prepared to contribute to national development efforts.

\section{The Constitutional Challenge/Drawbacks}

Since Nigeria independence, the country has been facing the challenge of crafting a constitution that has the backing of an overwhelming majority of Nigerians. In the 1940s and 1950s, our founding fathers battled with this problem. In the end, they arrived at the principle of federalism as a foundation for our nation. But federalism has faced stiff challenges over the years from those wanting a unitary form of government on the one hand, and from those wanting a confederal arrangement, on the other. To my mind, the worst enemies of Nigerian federalism are those who speak of federalism, but act in a unitary fashion by brushing aside all the divisions of powers between different levels of our federation. Related to the problem of federalism is the question of fiscal federalism. What is the appropriate and just basis for sharing revenue? Should the federal government have the right to deduct monies due to states without their permission? Should state governments continue to control local government allocations? These are all fundamental principles on which we have no clear consensus. While we all agree that Nigeria must be federal, we have no clear consensus on the nature of that federation, on whether we should have territorially defined states or ethnically defined states; as some are 
demanding. We also do not have a consensus on the number of states our federating units should have. While some are satisfied with the current 36 states, others are calling for more states while some says it should be reduced to 6 . Here again, there is little or no consensus.

Another constitutional challenge relates to the nature of our democracy. While most Nigerians support the principles of democracy such as the forming of government based on the will of the majority, respect for the rule of law, and respect for basic freedoms of citizens, the fact remains that in practice, we have tended to have either military rule or defective civilian governments.

Either in terms of accountability, or respect for the rule of law, or the holding of elections, our conduct in the recent past has been far from democratic. Therefore, while most of us now agreed that we do not want military rule, our visions and practice of democracy are not uniform, showing a fundamental lack of consensus on this important question as well. Moreover, our political parties should need to become little more than vehicles to deliver power to the highest, bidders at local, state and federal levels.

A third and final area of constitutional challenge which is worthy of mention is about the principles for sharing power at the different levels of government. As studies by the United Nations Research Institute for Social Development (UNRI5D) based in Geneva show, some sections of the country dominate the bureaucracy, while others dominate the cabinet and others dominate commerce and trade. This pattern of uneven distribution of power goes right down to even local governments. For example, through the work of the Federal Character Commission, we know that a local government in Warri once had staff from only one ethnic group, even though three ethnic groups lived in the local government area. Unless we have inclusive systems of government, we cannot have a stable political system as an anchor for development. Through the Federal Character Commission and through informal arrangements like 
zoning, we have made some progress, but a lot more work has to be done before we fully address the problem of monopoly, marginalization,' and exclusion in bureaucratic and political positions. Moreover, tine pursuit of the principle of the federal character should not be at the expense of merit or a substitute of equal opportunity for all citizens.

It is arguable therefore, that the key values of federalism, democracy, and inclusive government have not been sufficiently consolidated as core values for our nation. Some important questions regarding each of .these three key values remain unanswered. And in many instance, there is a discrepancy between what is written on paper and what people do in practice. Building consensus aroundthese three key values remains a constitutional challenge for development. Nigeria needs a constitutional arrangement that commands the acceptance, if not the respect, of a majority of its 140 million citizens. The 1999 constitution as amended bequeathed by the military is defective in many important respects. Attempts to correct these defects through the National Political Reform Conference (NPRC) of 2005 and the Constitutional Reform Bill of 2006 failed. Efforts are presently being made to amend the required sections of the constitution to being it in tune with the aspiration of the people.

\section{The Challenge of Building Institutions for Democracy and Development}

One of the greatest challenges of development in Nigeria is the challenge of institution building. Whether nations are able to manage their political and social disputes peacefully, without lapsing into conflict, or sustain economic, growth without creating huge inequalities, critically depend on the quality of the relevant national institutions.

There are three important components to institution building: setting the rules hiring persons with the expertise and moral 
competence to interpret the rules and implement the goals of the organizations'; and ensuring that the institutions inspire public confidence by being transparent, fair and consistent. These are also the standards by which the performance of any organization, in particular, public sector organizations should be measured. This shows that the act of creating the organization itself is not as important as its proper functioning and overall effectiveness. In this regard, Nigeria needs to create or strengthen institutions that would help achieve the national goals of democratic governance and sustainable development. Some of these institutions include the following:

\section{(a) Institutions for Fostering Public Integrity}

When we refer to the courts or the ICPC or Economic and Financial Crime Commission (EFCC) as institutions that fight corruption; we imply that these organizations operate and enforce a set of rules to create a system of values that rejects the abuse of public position for private gains.

Today, there are three institutions that are dedicated to fostering integrity in the public sector: the Code of Conduct Bureau (CCB), the ICPC and EFCC. Together the ICPC's mandate include reviewing public sector systems and procedures with a view to eliminating pitfalls for corruption, public enlightenment and mobilization against corruption and enforcing the law in these areas. By contrast, EFCC has mandate to combat 419 crimes, money laundering, and terrorist financing and fraud in the financial sector. Yet, there is also growing sense among the public that there is an overlap in functions between the ICPC and EFCC. However, those knowledgeable with the states creating the ICPC and EFCC argue that the main area of overlap is in the definition of economic crime as including corruption. The anti-corruption bodies have met the criteria of inspiring public, confidence in their work. 


\section{(b) Institutions for Public Service Delivery}

The civil service is the main instrument and institution of public service delivery. Traditionally, the civil service performs three functions: supporting the policy making function of government at the federal, state and local government; facilitating or regulating the private sector; and providing managerial leadership of operating public sector enterprises. The capacity of the Nigerian civil service to perform its statutory functions is critically dependent on its ability to attract and retain competent and highly skilled persons in the professional category; the will to offer attractive pay and benefits package; and the modernization of the office infrastructure.

The reforms of the federal civil service has rightly focused on improving the pay package, increasing the number of staff in the professional category through training and re-raining and improving service to the public through the Service Compact with Nigerians (Servcom).

Nonetheless, much remains to be done both in improving the office infrastructure in the civil service and in bringing public servants attitude to the standards of many emerging economies. Moreover, it is doubtful whether the new pay scale has done much to improve overall conditions of major incentive to work harder and show commitment to public service.

\section{(c) The Judicial Institutions}

The judiciary is an important institution in any democracy and it is also essential to the functioning of a market economy. The judiciary not only arbitrates disputes between the various levels of government, between government and citizens, and among citizens but also among private sector agents. Institutions of judiciary should have persons with the balanced intellectual standing and moral competence to interpret the rules or implement the goals of the organizations; and ensure that the institutions inspire public confidence. 
In recent times, the Supreme Court, the apex court of the land, has inspired much public confidence and respect because of the quality of its judgment, especially in some politically sensitive cases. In some ways, the gradual maturity of the democratic process in Nigeria, where politicians now prefer legal recourse rather to local rampage with their supporters and loyalists, is directly linked to the growing public confidence in the courts. Election related disputes should be addressed in the courts-be they election tribunals or ultimately in judicial courts -and not through violence.

There are multiplying instances of election-related violence tearing apart the social fabric in several African countries. Nigerians have also needlessly shed much blood in the past. If Nigerians are beginning to realize the futility of shedding blood in election disputes, this owes much to our judiciary, which has provided seasoned judgment on several cases. Nonetheless, the responsibility for conducting free and fair elections and accepting results should not be left to the judiciary alone. Democracy cannot be built solely on court orders or judgment of electoral tribunals.

\section{(d) Institutions for Economic Governance}

The functioning and effectiveness of a market-based economy such as Nigeria relies on several institutions. It requires an institution to regulate the supply and flow of money and the financial system (Central Bank); to allocate capital to firms and individuals (Banks and Stock Exchange); to insure against commercial risks (insurance firms); to insure individual bank depositors against loss of up to certain .amount (deposit insurance); to enforce contractual obligations (courts); and to collect revenue for the government (fiscal authorities). The performance of our national institutions of economic governance is a mixed one. However, the reform of the financial sector has strengthened public confidence in the banks especially and opened opportunities for our banks to extend their reach to other parts of the 
region. This has being largely made possible by the deployment of officers with the right intellect in Banking. How to spread the benefits of growth and development to all-in other words to achieve equitable growth is a major public policy challenge. In Nigeria, little effort has been made in that direction.

\section{(e) The Leadership Challenge}

Leadership is a critical factor in development and it should be understood in two important but related ways. Firstly, there are the personal qualities of integrity, honesty, commitment, and competence of individual leaders at the top. Secondly, there are the collective qualities of common vision, focus, and desire for development of the elites as a whole.

The standards for recruitment and the performance of our individual leaders over the years have left much to be desired. We do not need leaders who see themselves as champions of only some sections of our population. We do not need leaders who do not understand the economic and political problems of the country, not to talk of finding durable solutions for them. We do not need leaders who are more interested in silencing their opponents, than in pursuing justice.

We do not need leaders, who preach one thing, and do the exact opposite. We do not need leaders who: place themselves above the constitution and the laws of the country, but leaders who lead by upholding and respecting the law. We do not need leaders who have no sense of tomorrow, other than that of their private -.bank transactions.

If Nigeria must succeed in its development efforts we must have a leadership that is committed to the rule of law and has a demonstrable sense of fairplay and democratic tolerance; a: leadership with ability and integrity; above all else, we must have a leadership that can see beyond the ostentatious pomp of office. We must have 
leaders who have a vision for Nigeria better than the one they inherited; leaders who will lead by deeds and not by words; achievers, not deceivers. We need a leadership that will not only leave its footprints on the sands of time, but one, which by dint of hard-work, fairplay, dedication and commitment, will live forever in the hearts of Nigerians.

Leadership is not everything, but it is an extremely important factor. Unless we have leaders with ability, integrity, commitment, and vision, we cannot succeed at developing Nigeria. It is gratifying to note that within the judiciary, the National Assembly, and within the Executive, the issue of the quality of 'leadership is currently receiving attention. We must not relent in this struggle for quality leadership as it is the key to building our nation.

Beyond the qualities of individual leaders, however, there is the equally important question of the quality of the collective leadership offered by the Nigerian elite class as a whole. After all, a tree cannot make a forest, and an individual leader cannot do everything alone. Do we have an elite that is collectively committed to developing Nigeria?

In answering this question, let us beam our searchlight at two very similar African countries in which leadership has made the critical difference. Colleagues in the field of comparative politics have pointed out that Botswana and Somalia are quite similar when you look at their fundamental characteristics. Both have: (1) one large dominant ethnic group divided into clans; (2) both are sparsely populated in semi-arid conditions; (3) at independence, both depended on livestock for the livelihood of a majority of the population. While the Botswana leadership was collectively focused and had a vision of what it wanted to do with the country, the leadership in Somalia was divided against itself. As a result, Botswana learnt to harness its limited resources for generally agreed objectives. It learnt to survive under the shadow of apartheid South 
Africa. And it learnt to manage its diamond resources well when those resources started flowing in. Somalia, on the other hand had a divided leadership, some of whom wanted to build Greater Somalia by military means, while others simply wanted to get on with running the country they inherited from colonialism. As a result, the Somali leadership lacked focus and vision, and often fought itself through conspiracies and military coups. Somalia also went to war with its neighbours. For anybody looking at these two countries today, the difference is clear.

The comparative histories of Botswana and Somalia suggest that we should be concerned not just with the quality of leadership of our Presidents, Governors, Senators and Judges; we should also be concerned with the quality of leadership which we all bring to our professional and personal responsibilities. Development is a collective responsibility that requires the contribution of everybody.

When a Nigerian leader, by words and deeds, is able to convince a large enough section of the Nigerian elites and the wider public about a vision for a greater tomorrow, then Nigeria will truly be on the way to national greatness. While our experiences in the past have been disappointing, we have every reason to believe that the future is likely to be better.

\section{Conclusion}

No nation can .exist in isolation and development must take account of the international context of the country in question. The external dimensions of our development agenda, in the framework of concentric circles of interest and influence, must necessarily take account of our responsibilities and obligations in the West African sub-region, within Africa, and in the world as a whole since the challenges facing the international system defy purely national solutions. Nigeria has played an important role in the international relations of West Africa, Africa and the Black race. We must continue to do so, but at the same time, resist the temptation of seeing ourselves as the new 'policeman' of West Africa. 
The promotion of regional security and peace through ECOMOG must be complemented by: strategies emphasizing the creation of common regional economic infrastructure, the expansion of economic opportunities, and the promotion, of democratic institutions and values. The promotion of democratization and sustainable development both in our region and in Africa as a whole is central to Nigeria's national interest.

Conclusively Nigeria can only be developed by men and women who have the will and vision to accomplish greatness, not for themselves, their immediate families and friends, but for their country. I believe that if we can find the will to offer such a leadership, and support it by strong and dependable political and economic institutions, we will find a way to our national greatness.

\author{
Aaron Onyemaechi Nwokolo \\ Department of Political Science \\ College of Education, Agbor \\ onyeaaron@gmail.com
}

\title{
References
}

Adebayo, A. (1981) Principles and Practice of Public Administration. New York: John Wiley and Sons.

Central Bank of Nigeria (2006) Annual Report and Statement of Account Abuja: Government Press.

Jhingan, M.L. (1975) The Economics of Development and Planning. lndia: Vani Educational Books.

Ndoh, C.A. (1995) imperialism and Economic Dependency in Nigeria. Owerri: Charismatic Forum Publication.

Rodney, W. (1972) How Europe Underdeveloped Africa. London: Bigle Loverture Publication.

Soludo, C. (2010) Nigerians may Revolt against Bad Governance Lagos: Vanguard Media Limited. 